\title{
The Effects of Treadmill Training on Neurotrophins and Immediately Early Protein in Obese Rats
}

\author{
Jinhee Woo', Ki Ok Shin', Nam Heoh Yeo', So Young Park ${ }^{2}$ and Sunghwun Kang ${ }^{1,2}{ }_{\star}$ \\ ${ }^{1}$ Department of Physical Education, Dong-A University, Busan 604714, Korea \\ ${ }^{2}$ Department of Pharmacology, Dong-A University, Busan 602-103, Korea
}

Received April 5, 2011 /Revised June 24, 2011 /Accepted July 15, 2011

\begin{abstract}
The purpose of this study was to investigate the biological effect of obesity-induced oxidative damage on neurogenesis and early protein expression. Obesity was induced I thirty 4-week old male Sprague-Dawley rats through a high fat diet for 15 weeks. After one week of environmental adaptation, the rats were divided into 2 groups: high fat diet sedentary group (HDS, $n=15)$ and high fat diet training group (HDT, $n=15$ ). Exercise training was performed 5 times a week for 8 weeks, with mild-intensity treadmill running for weeks 1-4 and moderate-intensity treadmill running for weeks 5-8. After the 8 week training period, we analyzed lipid profiles, serum 8-hydroxyguanosine (8-OHdG), liver tissue malondialdehyde (MDA) related to oxidative damage factors, nerve growth factor (NGF), brain derived neurotrophic factor (BDNF), c-fos, c-jun, and extracellular signal regulated kinase (Erk) in the hippocampus. The results of this study are as follows. There were differences between HDS and HDT in triglyceride (TG) and total cholesterol (TC) $(p<0.05)$. In high density lipoprotein (HDL-c), the HDT was higher than HDS after treadmill training $(p<0.05)$. In 8-OHdG, the HDT was lower than HDS after treadmill training $(p<0.05)$. Genetic expressions of c-jun, BDNF and MDA in the HDT were higher than in the HDS after treadmill training in hippocampus $(p<0.05)$. Therefore, we conclude that 8 weeks of treadmill training can improve imbalanced lipid profiles, reduce oxidative damage, and activate neurogenesis in obese rats.
\end{abstract}

Key words : Neurogenesis, 8-OHdG, BDNF, c-fos, c-jun

\section{서 론}

비만은 면역체계 이상을 초래하여 염증반응으로 이어지는 원인이 된다[22]. 이러한 염증반응은 산화적 스트레스와 관련 있으며[31], 산화적 스트레스를 유발시키는 활성산소종 (reactive oxygen species, ROS)은 세포의 손상과 신경변성 (neurodegenerative) 및 세포사를 유발하는 것으로 알려져 있 다[5,8].

신경세포의 손상과 조절을 담당하는 neurotrophin (NT)는 nerve growth factor (NGF), brain-derived neurotrophic factor (BDNF), NT-3, 그리고 NT-4로 분류된다[11]. NGF는 뉴런 의 목표에 의해 분비되는 단백질이며, 교감 및 감각뉴런 유지 와 더불어 세포성장을 포함하는 생물학적 활동에 중요한 역할 을 담당한다[31]. 그리고 최근 염증반응과 면역계통 질환의 진 행에도 관여하는 것으로 보고되고 있다[3]. 선행연구에 의하면 혈장 NGF 수준은 고도 비만인 경우 낮게 나타나며, 또한 염증 요인, $\mathrm{BMI}$, 체지방율 그리고 허리둘레와 높은 상관을 가지고

*Corresponding author Tel : +82-51-200-7887, Fax : +82-51-200-7805

E-mail : 94psycho@naver.com
있다[3]. NGF는 갈색 지방세포에서 합성되어 분비되므로 유 전적으로 마른 동물모델 보다는 비만 동물모델에서 높게 나타 난다고 최초로 밝혔지만, 연령에 따라 차이가 존재한다고 하 였으며[20], 인간을 대상으로 한 연구에서 성인의 경우 정상체 중보다는 비만인의 NGF가 높고[3], 고도비만보다는 과체중인 피험자의 NGF가 더 높게 나타났다고 하여, 비만 수준과 연령 에 따라 차이를 보이고 있어 조직수준에서의 연구가 절실히 필요하다.

한편, BDNF는 뇌뿐만 아니라 말초에서도 발견되는 단백질 로서 중추신경계와 말초신경계의 특정 뉴런에서 활성 되어 뉴런이 생존하는데 지원해주는 역할을 한다. 또한, 신생 뉴런 과 시냅스의 성장과 분화를 도와주어 학습, 기억, 그리고 사고 력 활성을 위한 역할을 수행하는 것으로 운동으로 neurogenesis를 자극하고 뇌손상을 예방하며, 학습과 정신적 기능 강화[6]는 물론, 세포 성장의 주요한 조절자로서 긍정적인 역 할을 수행하는 것으로 알려져 있다[36]. NT에 의한 신경 세포 성장 기전을 살펴보면, 4 개의 NT (NGF, BDNF, NT-3, NT-4) 는 그들과 상응하는 Trk-A, Trk-B와 Trk-C에 의해서 발현되며 $[12,34], \mathrm{MEK} 1 / 2, \mathrm{SEK}$ 와 $\mathrm{MKK} 3 / 6$ 에 의하여 $\mathrm{MAPK}$ 가 활성화 되고[28], 이러한 $\mathrm{MAPK}$ 는 신호 기전의 활성으로 초기발현 유 
전자(immediately early gene, IEG)를 발현 시킨다[26]. 초기발 현 유전자는 세포외부의 자극에 가장 먼저 반응하는 전사 (transcription)이며, c-fos, fosB, fosBdel, fra-2, c-jun, junB, $\mathrm{junD}$ 등으로 분류된다[16]. 이들은 전사조절인자로서 세포의 증식, 분화, 세포사, 종양형성과 유전자의 발현 등 다양한 세포 과정을 조절하는데 관여 한다[1].

운동과 관련된 연구를 살펴보면, Toldy 등[35]은 쥐를 대 상으로 6 주간의 수영 운동 후 c-jun 발현이 활성화되었다고 하였으며, Iemitsu 등[13]은 48시간의 트레드밀 운동이 그렇 지 않은 그룹보다 c-jun과 c-fos의 단백질 발현이 증가함을 보고하였다. 또한 $\operatorname{Sim}$ 등[30]은 알코올을 통한 산화스트레 스를 증가시킨 결과 c-fos의 발현이 감소하며, 가벼운 강도 와 적정 강도의 운동 이후 c-fos발현이 증가함을 보고하여 규칙적인 운동이 유기체의 세포 성장에 긍정적인 영향을 준 다고 하였다.

이처럼 규칙적인 운동이 비만을 개선시킴으로써 산화적 스트레스와 neurogensis 과정에 긍정적인 영향을 줄 수 있 다고 가정해 볼 때, 산화적 스트레스는 비만과 관련이 있으 며, 이는 NGF 및 $\mathrm{BDNF}$ 발현과 이들을 조절하는 전사인자 들 발현의 변화를 유도함으로써 나타난다. 그러나 운동에 의한 항비만 효과에 이러한 기전들이 어떻게 작용하는지에 대해서는 아직 알려진바 없다. 또한 비만으로 인한 산화적 스트레스 증가가 규칙적인 운동으로 산화적 스트레스 감소 를 통하여 뇌 조직의 IEGs (c-fos, c-jun)에 어떠한 영향을 주 는지 규명하는 연구가 절실히 필요하다. 따라서 본 연구는 고지방식이 비만유도 rat을 대상으로 조직의 산화적 손상이 neurogenesis 과정에 어떠한 영향을 미치는지 알아보고, 규 칙적인 유산소성 운동으로 인한 개선 효과를 분자 생물학적 차원에서 규명하고자 한다.

\section{재료 및 방법}

\section{실험동물과 환경조건}

본 연구에 사용된 동물은 국가공인 동물취급업체로부터 분 양 받은 Sprague-Dawley 수컷 흰쥐(4주령) 30마리로서 D대학 교 의과대학 동물실험실에서 한 cage에 2마리씩 넣어 사육하 였다. 동물 사육실은 high efficiency particulate arrestant (HEPA) 항시 무균청정공기를 공급시키는 필터와 외부의 오 염공기가 차단되는 양압 설비를 갖추고 있으며, 사육실 내의 온도는 $22-24{ }^{\circ} \mathrm{C}$, 습도는 $60 \%$, 조명 등이 자동 제어되어 일정한 조건의 사육환경이 제공될 수 있는 시설을 갖추었다. 모든 실 험은 $\mathrm{D}$ 대학교 의학연구소와 동물실험위원회 지침에 따라 시 행하였다.

\section{식이섭취 및 체중변화}

1 주일간의 환경적응(일반식이: Dong-a SF, Korea)을 시킨
후, 15 주간 모든 필수 영양소, vitamin과 mineral, 그리고 fat $40 \%$ 가 함유된 AIN-76A (Jung-ang Lab. Animal, Inc. Korea) 을 물과 함께 공급하여 비만을 유도 하였다. 15 주간 비만 유도 후, 비만식이 비훈련군(high fat diet sedentary, HDS, n=15), 비만식이 훈련군(high fat diet training, HDT, n=15)으로 분류 하여 사육하였다. 실험 기간 동안 식이 섭취량은 매일 같은 시각(18:00)에 측정하였으며, 체중은 매주 1회(18:30) 일정한 시간에 computingscale 체중계(CAS, Korea)를 이용하여 측정 하였고, 식이섭취에 의한 일시적인 체중 변화를 막기 위해 측 정 2시간 전에 식이 그릇을 제거한 후 실시 하였다.

\section{운동프로그램}

운동 프로그램은 15 주간 고지방식이를 통해 비만을 유도한 후, $\operatorname{Sim}$ 등[30]의 연구에서 사용된 방법과 동일하게, 주 5 일, 1 일 40 분씩 8 주간 실시하였다. 트레드밀 운동은 1 4주는 경사 도 $0^{\circ}$ 고정된 조건에서 처음 5 분간은 $2 \mathrm{~m} / \mathrm{min}$ 의 속도로, 다음 5 분간은 $5 \mathrm{~m} / \mathrm{min}$ 의 속도로, 그리고 남은 30 분 동안은 8 $\mathrm{m} / \mathrm{min}$ 의 속도로 실시하였다. 5 주에서 8 주는 경사도 $0^{\circ}$ 고정 된 조건에서 처음 10 분간은 $8 \mathrm{~m} / \mathrm{min}$ 의 속도로, 다음 10 분간 은 $11 \mathrm{~m} / \mathrm{min}$ 의 속도로, 그리고 나머지 40 분 동안은 14 $\mathrm{m} / \mathrm{min}$ 의 속도로 실시하였다.

\section{공간적 인지학습 능력}

두 그룹 내 운동과 비운동군 뇌 인지기능의 효과를 검증하 기 위해 Morris water maze (MWM)를 사용하였다[18]. 실험 절차는 미로학습 검사를 시작하기 하루 전에 도피대가 없는 상태에서 수영풀 안을 60 초 동안 자유롭게 수영하도록 하여 물에 대한 적응을 유도하였으며, 훈련이 시작되면 동물은 4 사 분면 중 한쪽에서 동물의 머리가 벽면을 향하도록 하여 살며 시 물 안으로 놓아주어, 2그룹 모두 3일 동안 총 6회 실시하여 platform을 찾아 올라갈 때까지의 잠재기를 측정하였다.

\section{채혈 및 조직 샘플링}

트레드밀 훈련 전과 후에 꼬리 정맥에서 $1 \mathrm{ml}$ 의 혈액을 채 혈하였으며, 혈청지질성분과 8-OHdG를 분석하였다. 트레드 밀 훈련 후 채혈과 조직샘플링은 일시적인 운동 효과를 배제 하기 위해, 훈련종료 48 시간 경과 후에 실시하였으며, 사료는 12 시간 전에 공급을 중단하였지만, 음수는 계속 제공하였다. 실험동물들은 충분한 안정을 취한 뒤 마취제 에틸에테르 (ethyl ether)를 이용하여 마취 시켰다. 마취된 실험동물은 해 부판 위에 사지를 고정시키고, $70 \%$ 알코올 분무기로 분무한 후, 복부를 절개하여 복부 정맥에서 $10 \mathrm{ml}$ 의 정맥혈을 채혈 하였으며, 이후 약 $3 \mathrm{~g}$ 의 해마와 $5 \mathrm{~g}$ 의 간을 샘플링 하였다. 두 조직은 deepfreezer (MVE Co., USA)에 넣어 $-80^{\circ} \mathrm{C}$ 상태로 보관한 뒤 분석하였다. 


\section{생화학적 분자생물학적 분석}

\section{Lipid profiles}

$\mathrm{TC}, \mathrm{TG}$, 및 $\mathrm{HDL}-\mathrm{C}$ 함량은 효소법에 의한 정량용 kit (각각 AM201-K, AM202-K, AM157S-K, AM203-K, Asan Co., Korea)로 측정하였다. 혈청 $0.002 \mathrm{ml}$ 에 효소용액 $0.3 \mathrm{ml}$ 를 첨 가하여 교반하고, $37^{\circ} \mathrm{C}$ 수조에서 5 분간 반응시켜 발색시킨 후 blank를 대조로 하여 분광광도계(UVmini-1240, Shimadzu Co., Japan)로 흡광도를 측정하였다.

\section{8-hydroxy-2'-deoxyguanosine (8-OHdG)}

산화적 DNA 손상의 지표로 이용되는 8-OHdG는 DNA damage ELISA kit (Assay Designs, USA)로 측정하였다. Sample diluent에서 8-OHdG standard와 sample을 준비한 다 음, 8-OHdG immunoassay plate의 각 well에 standard와 sample을 $50 \mu 1$ 를 첨가하였으며, 각 well에 anti-8-OHdG를 $50 \mu \mathrm{l}$ 첨가하였다. 그 후 1시간 실온에서 incubate하고, wash buffer $300 \mu 1$ 로 6번 씻어낸 다음, 각 well에 anti-Mouse IgG: $\mathrm{HRP}$ cohjugate를 $100 \mu \mathrm{l}$ 첨가하였다. 그 후 다시 1 시간 동안 실온에서 incubate 한 후, 각 well에 TMB substrate $100 \mu 1$ 를 첨가하였다. 다시 실온에서 15분 동안 incubate 한 후, $450 \mathrm{~nm}$ 흡광도를 통해 측정하였다.

\section{Western blot}

인지기능의 주요 담당과 초기 발현 단백질의 발현이 가장 두드러진 Hippocampus (c-fos, c-jun, Erk, BDNF, NGF)와 산 화적 스트레스를 조절하는 liver (MDA)의 protein을 분리하기 위해서 radioimmunoprecipitation assay (RIPA) buffer [50 $\mathrm{mM}$ Tris- $\mathrm{HCl}, \mathrm{pH}$ 8.0, with $150 \mathrm{mM}$ sodium chloride, 1.0\% Igepal CA-630 (NP-40), 0.5\% sodium deoxycholate, $0.1 \%$ sodium dodecyl sulfate, Protease Inhibitor Cocktail and Phosphatase Inhibitor Cocktails] $200 \mu 1$ 를 넣고 homogenazer 로 조직을 균질화 한 다음, 30 분간 ice incubation하여 hippo- campus를 융해시키고, $13,000 \mathrm{rpm}, 30$ 분간 $4^{\circ} \mathrm{C}$ 에서 원심분리 하여 상층액만을 깨끗한 e-tube에 옮기고 사용 하기 전 까지 $-70^{\circ} \mathrm{C}$ 에 보관하였다. Western blot 실험을 시작하기 전 $\mathrm{BCA}^{\mathrm{TM}}$ protein assay kit (PIERCE, IL)로 단백질을 정량한 다음 SDS-polyacrylamide gel electrophoresis (SDS-PAGE)에 로딩 하여 전기영동을 하고 $100 \mathrm{~V}$ 에서 membrane에 옮긴 후 $5 \%$ SKIM MILK로 blocking하였다. 1차 antibody NGF (sc-548)와 BDNF (sc-546), b-actin (sc-1616) (Santa Cruz biotechnology, Santa, CA, USA), Erk (AF 1576), c-fos, c-jun (R\&D system, Minneapolis, MN, USA), MDA를 $4^{\circ} \mathrm{C}$ 에서 overnight 반응하 였으며, 2차 antibody를 실온에서 1시간 반응한 뒤 ECL solution (Amersham Pharmacia Biotech, Piscataway, NJ)으로 발색한 뒤 LAS-3000으로 단백질 발현을 확인하였다.

\section{자료처리}

본 연구에서 얻은 자료는 SPSS Windows Ver 14.0 통계 package를 이용하여, 모든 측정항목에 대해 평균과 표준 편차 를 산출하였다. 집단 간의 트레이닝에 따른 혈액성분에 대한 차이검증을 위해 이원분산 분석(two-way ANOVA)을 이용하 였으며, 시기 간 차이가 있을 시 대응표본 t-test를 실시하였고, 집단 간 차이가 있을 시 독립표본 t-test를 실시하였다. 조직분 석은 독립표본 t-test를 실시하였으며, 모든 통계적 유의 수준 은 $\mathrm{a}=0.05$ 로 설정하였다.

\section{결 과}

Table 1에서 체중은 HDT 군에서 트레드밀 훈련 후 유의하 게 감소하였으며, 또한 그룹간의 차이가 나타났다 $(p<0.05)$.

Table 2와 같이 공간학습효과를 알아보기 위해 MWM latency 방법을 이용한 결과 두 그룹 모두 첫날에 비해 3일째에 유의하게 시간을 단축하였다( $p \ll 0.05)$. 또한 3 일째 그릅간의 비

Table 1. Changes of 8 weeks on body weight after treadmill training pre and post

\begin{tabular}{cccccc}
\hline \multirow{2}{*}{ Variable } & Group & $\begin{array}{c}\text { Pre } \\
(\mathrm{M} \pm \mathrm{SD})\end{array}$ & $\begin{array}{c}\text { Post } \\
(\mathrm{M} \pm \mathrm{SD})\end{array}$ & \multicolumn{2}{c}{ F-values in two-way ANOVA } \\
\cline { 5 - 6 } & & $610.16 \pm 13.43$ & $613.41 \pm 20.29$ & Group & Period \\
\hline Weight & HDS $(\mathrm{n}=15)$ & $608.66 \pm 5.55$ & $533.33 \pm 14.03^{*}$, \# & 10.003 & 5.490 \\
\hline
\end{tabular}

HDS: High fat diet sedentary, HDT: High fat diet and training

*: $p<0.05$ significantly difference from pre

\#: $p<0.05$ significantly difference between groups

Table 2. Water maze time

\begin{tabular}{ccccc}
\hline Variable & Group & Day 1 & Day 2 & Day 3 \\
\hline Water maze time & HDS $(\mathrm{n}=15)$ & $43.80 \pm 4.42$ & $30.95 \pm 3.11^{*}$ & $29.55 \pm 2.54^{*}$ \\
$(\mathrm{sec})$ & HDT $(\mathrm{n}=15)$ & $41.92 \pm 3.37$ & $33.29 \pm 3.95^{*}$ & $21.75 \pm 3.85^{*}$, \\
\hline
\end{tabular}

*: $p<0.05$ significantly difference from day 1

\#: $p<0.05$ significantly difference between groups 
Table 3. Change of 8 weeks on glucose and lipid profiles after treadmill training pre and post

\begin{tabular}{|c|c|c|c|c|c|}
\hline \multirow{2}{*}{ Variable } & \multirow{2}{*}{ Group } & \multirow{2}{*}{$\begin{array}{c}\text { Pre } \\
(\mathrm{M} \pm \mathrm{SD})\end{array}$} & \multirow{2}{*}{$\begin{array}{c}\text { Post } \\
(\mathrm{M} \pm \mathrm{SD})\end{array}$} & \multicolumn{2}{|c|}{ F-values in two-way ANOVA } \\
\hline & & & & Group & Period \\
\hline \multirow{2}{*}{$\begin{array}{c}\text { TG } \\
(\mathrm{mg} / \mathrm{dl})\end{array}$} & HDS $(n=15)$ & $141.37 \pm 15.25$ & $175.42 \pm 21.49^{*}$ & \multirow{2}{*}{15.014} & \multirow{2}{*}{9.010} \\
\hline & HDT $(n=15)$ & $131.42 \pm 7.39$ & $145.75 \pm 15.34^{\#}$ & & \\
\hline \multirow{2}{*}{$\begin{array}{c}\mathrm{TC} \\
(\mathrm{mg} / \mathrm{dl})\end{array}$} & HDS $(n=15)$ & $145.32 \pm 8.29$ & $217.97 \pm 32.88^{*}$ & \multirow{2}{*}{11.294} & \multirow{2}{*}{23.336} \\
\hline & HDT $(n=15)$ & $148.61 \pm 7.46$ & $168.06 \pm 15.29^{\#}$ & & \\
\hline \multirow{2}{*}{$\begin{array}{l}\text { HDL-c } \\
(\mathrm{mg} / \mathrm{dl})\end{array}$} & HDS $(n=15)$ & $67.91 \pm 13.66$ & $72.61 \pm 8.88$ & \multirow{2}{*}{.215} & \multirow{2}{*}{6.634} \\
\hline & HDT $(n=15)$ & $67.02 \pm 10.19$ & $75.95 \pm 7.29^{*}$ & & \\
\hline
\end{tabular}

TG: Triglyceride, TC: Total Cholesterol, HDL-c: High density lipoprotein cholesterol

*: $p<0.05$ significantly difference from pre

\#: $p<0.05$ significantly difference between groups

교에서 $\mathrm{HDT}$ 가 $\mathrm{HDS}$ 보다 유의하게 시간을 단축시켰다 $(p<0.05)$.

Table 3에서 혈청지질 성분의 분석 결과HDS군에서 $\mathrm{TG}$ 와 $\mathrm{TC}$ 모두 8주 전에 비해 후에서 유의하게 증가하였으며 ( $p<0.05)$, post 시점의 그룹간 비교는 HDS군에 비해 HDT군이 유의하게 낮게 나타났다( $p \times 0.05)$. 그리고 HDL-c은 그룹 간 유 의한 차이가 나타나지 않았지만, HDT군에서 8주간의 트레드 밀 훈련 전에 비해 훈련 후 유의한 증가가 나타났다 $(p<0.05)$. 산화적 DNA 손상의 지표인 $8-\mathrm{OHdG}$ 는 Fig. 1 과 같이 $\mathrm{HDS}$ 군에서 8 주 전후 유의한 차이가 나타났지만( $p<0.05)$, HDT군은 8주간의 트레드밀 훈련 전후 차이가 없었다. 또한 훈련 후 HDT에 비해 HDS 수준이 높게 나타났다.

Fig. 3과 같이 해마에서 c-fos, Erk 그리고 NGF는 8주간의 트레드밀 훈련 후 그룹간 유의한 차이는 나타나지 않았다. 하 지만 c-jun과 BDNF는 8주간의 트레드밀 훈련 후 HDT군이 $\mathrm{HDS}$ 군보다 유의하게 높은 것으로 나타났다 $(p<0.05)$. 뿐만 아 니라, Fig. 2와 같이 간에서 $\mathrm{MDA}$ 는 8주간의 트레드밀 훈련 후 HDT군이 HDS군보다 유의하게 낮게 나타났다( $p<0.05)$.

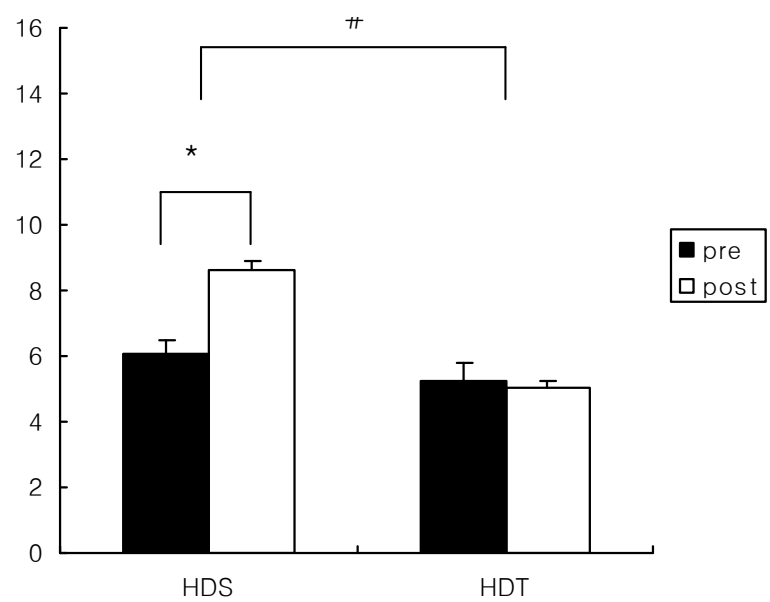

Fig. 1. Change of serum 8-OHdG after treadmill training. *: $p<0.05$ significantly difference from pre, \#: $p<0.05$ significantly difference between groups

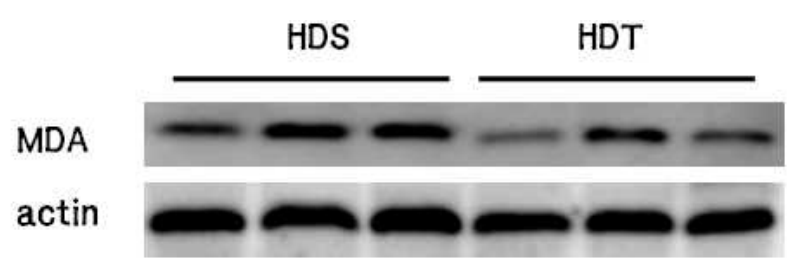

Fig. 2. MDA protein expression in liver.

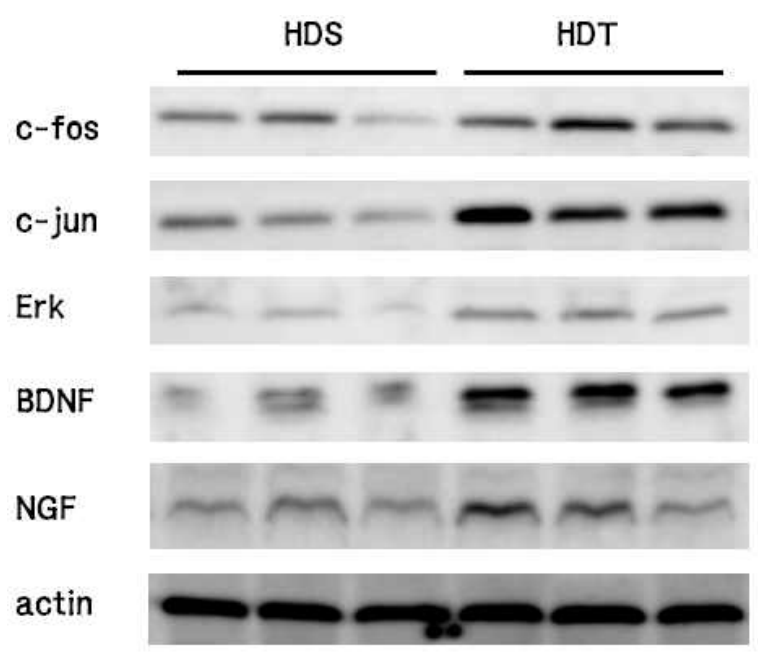

Fig. 3. Neurotrophins and IEG protein expression in hippocampus.

\section{고 찰}

고지방식이 비만 유도 쥐를 대상으로 8주간의 트레드밀 훈 련은 고지방 식이로 인한 혈청 지질성분의 불균형을 완화해주 었으며, 동시에 산화적 스트레스의 감소를 가져왔다. 그리고 규칙적인 유산소성 운동이 비만으로 발생된 뇌 성장 인자의 감소를 막아, NT와 초기발현 단백질 농도를 개선함으로써 뇌 기능 향상에 긍정적인 결과를 얻을 수 있었다.

운동의 긍정적 기능에도 불구하고 운동부족 현상은 증가하 고 있으며, 비만으로 인한 문제가 심각하다. 하지만 비만은 
규칙적인 운동을 통해 $\mathrm{HDL}-\mathrm{c}$ 의 증가와 $\mathrm{TC}, \mathrm{TG}$ 의 감소를 유도 하여 혈중지질 농도를 개선시키고, 합병증을 줄여준다[10]. 한 편, 비만에 따른 이상지질현상은 산화적 DNA 손상을 유발하 게 되며, 이러한 DNA 손상의 지표로써 8-OHdG와 MDA가 대표적이다. 고지방식이 rat을 대상으로 규칙적인 운동을 시 킨 결과 운동 후 rat의 혈중 8-OHdG 농도의 유의한 감소가 나타나 운동의 긍정적 영향을 보고하고 있으며[2,24], 또한 흰 쥐를 대상으로 12 주간 규칙적인 운동으로 산화적 스트레스의 지표인 혈중 $\mathrm{MDA}$ 농도가 감소됨을 발견하여 운동을 통한 산 화적 스트레스의 개선을 보고하고 있다[14]. 본 연구는 장기간 고지방식이 유도를 통하여 비만을 유발한 뒤 운동트레이닝의 효과를 분석하였다. 그 결과 TG와 TC 모두 지속적인 고지방식 이를 실시한 HDS 그룹에서 유의한 증가가 나타난 반면, HDT 그룹은 변화가 나타나지 않았다. 그리고 HDL-c는 HDT그룹에 서 유의한 증가가 나타났다. 이러한 결과는 고지방식이에 따 른 혈청지질의 불균형 현상이 규칙적인 운동으로 $\mathrm{TG}$ 와 $\mathrm{TC}$ 가 악화되는 것을 막아주며, HDL-c는 개선시키는 것으로 고지방 식이에 대한 지질성분의 불균형을 운동트레이닝으로 막을 수 있었다. 한편, 혈중 8-OHdG 농도와 간에서의 $\mathrm{MDA}$ 발현은 트레드밀 훈련 후 HDS 보다 HDT 그룹에서 유의하게 감소하 였다. 이러한 결과로 볼 때 지속적인 고지방 식이에도 불구하 고 규칙적인 운동은 체중 감소를 유도하고 산화적 스트레스에 의한 간에서의 조직 손상 악화를 효과적으로 방어해 준다고 볼 수 있다.

규칙적인 운동은 뇌 기능에 효과적이며[22,23], 최근 $\mathrm{BDNF}$ 를 향상시킴으로써 산화적 손상을 막아주는 긍정적 영향을 보고하고 있다[39]. 또한 운동중단(detraining) 후에 BDNF와 $\mathrm{NGF}$ 의 유의한 감소를 보고하여 지속적 운동을 강조하고 있다 [24]. 운동은 비만 rat [24]과 다발성 경화증 환자[27]의 NGF를 증가시켜 기억력을 향상시키는 것으로 알려져 있으며, $\mathrm{Yu}$ 등 [37]은 고지방식이로 인한 쥐의 해마에서 $\mathrm{BDNF}$ 의 감소를 보 고하였으며, 이러한 현상은 학습능력과 기억력 퇴화를 유발시 키는 원인으로 보고 있다[15]. 그리고 손상된 해마세포는 칼로 리 섭취 조절 능력 기억과 관련하여 악영향이 나타남으로써 과체중을 야기 시키는 것으로 보고하고 있다[10]. 한편 단 기간 (3일) 트레드밀 훈련은 $\mathrm{BDNF}$ 발현이 증가하여 인지기능을 향 상시키는 것으로 보고 되고 있으며[19], 트레드밀 훈련을 통하 여 $\mathrm{BDNF}$ 의 발현 증가와 공간학습 능력의 향상을 보고하였다 [38]. 하지만 인간을 대상으로 실시한 10주간 웨이트 훈련은 근력과 제지방(LBM) 체중은 증가하였으나 혈중 $\mathrm{BDNF}$ 의 변 화는 나타나지 않아 건강한 대상자의 경우 영향을 미치지 않 는 것으로 보고되고 있다[17]. 운동 이후 NT의 증가가 산화적 스트레스를 감소시킴으로써 free radical의 감소를 유발하며, $\mathrm{ROS}$ 의 수준을 긍정적으로 조절하기 위한 NT의 적응력 향상 으로 뇌기능 향상의 저해 요소인 산화적 손상을 완화하는 것
으로 보고되고 있다[29]. 본 연구에서 트레드밀 운동은 해마에 서 고지방식이 유도 비만 쥐의 감소된 $\mathrm{BDNF}$ 를 증가시켜 주는 것으로 나타났다. 한편, $\mathrm{BDNF}$ 의 downstream인 MAPK cascades중 Erk는 뇌의 학습과 기억, 그리고 synaptic plasticity와 같은 기능 조절을 담당하며[33], 3개의 주요한 cascade인 extracellular signal-regulated kinase (Erk), c-Jun NH2-terminal kinase (JNK) 그리고 p38 MAPK (p38)로 분류할 수 있다[28]. 운동과 관련된 선행연구를 보면, Chae 등[4]은 6주간의 트레드 밀 훈련이 Erk의 발현을 증가 시킨다고 하였으며, Iemitsu 등 [13]은 12주간의 트레드밀 훈련후 Erk의 발현이 증가한다고 보고하였다. 본 연구 결과 고지방 식이는 규칙적인 운동으로 산화적 스트레스 감소뿐만 아니라, 특히 선행연구와 같은 시 상하부가 아니 뇌의 해마에서 MAPK cascades의 Erk 발현 증 가현상을 가져왔으며, 또한 NTs의 긍정적 변화를 통해 감소된 $\mathrm{BDNF}$ 발현 증가를 가져온 것으로 사료된다.

IEG는 c-fos, fosB, fra-1, c-jun, junB, junD 등으로 구분되고 [1], 신경활동의 지표로서 면역변화, 뇌출혈, 소음, 운동과 같은 다양한 자극이 주어지면 매우 빠르고 정확하게 발현되는 것으 로 알려져 있다[7]. 그리고 세포의 증식, 분화, 세포사, 종양형 성과 유전자의 발현 등 다양한 세포과정을 조절한다[1]. 운동 은 NGF의 생성을 촉진하며, 그 하위 신호체계인 c-jun의 발현 을 통해 학습능력과 기억에 관하여 신경세포의 활성과 관련이 있는 것으로 보고 되고 있으며[21], 신경 표지자로 알려져 있는 c-jun은 신경의 재생과 관련되어 많은 연구가 수행 되어 오고 있다. 특히 Sim 등[30]은 해마에서 비만쥐와 마른쥐의 비교를 통해 비만쥐보다 마른쥐에서 c-jun의 발현이 증가한다고 하여 정상체중을 유지하는 것이 필수적임을 제시하였으며, Yanagita 등[37]은 시상하부에서 강제적인 wheel running 운 동 그룹이 그렇지 않은 그룹보다 c-jun 발현이 증가한다고 하 여 규칙적인 운동의 필요성을 제시하였다. 또한 Toldy 등[35] 은 전두엽과 소뇌에서 규칙적인 운동으로 c-jun이 증가한다고 보고하였으며, Iemitsu 등[13]은 심장에서 rats을 대상으로 48 시간의 트레드밀 운동이 그렇지 않은 그룹보다 c-jun의 발현이 증가 한다고 보고하였다. 본 연구 결과 해마에서 트레드밀 훈 련 후의 NGF의 단백질 발현이 증가되었으며, 또한 c-jun의 발현이 HDT 그룹에서 유의하게 증가한 것으로 나타났다. 뿐 만 아니라 인지기능 검사의 직접적인 효과로서 Water maze time을 유의하게 감소시켰다. 이러한 결과는 선행연구에서 시 상하부에 국한된 것과는 달리 운동의 긍정적 효과가 인지기능 과 학습능력에 직접적으로 관여하는 뇌의 해마에서 나타남으 로써 그 의미가 크다고 할 수 있다. 따라서 규칙적인 운동이 해마에서 NGF의 발현은 물론 c-jun의 발현을 증가 시켜 학습 능력과 기억력의 향상을 유발하였으며, 유기체의 신경세포성 장에 긍정적인 영향을 주게 되어 공간인지 능력의 향상을 가 져온 것으로 판단된다. 


\section{감사의 글}

이 논문은 2009년도 국민체육진흥공단 체육과학연구원의 체육학술진흥사업비에 의하여 연구되었음(KISS-09-A03003).

\section{References}

1. Angel, P. and M. Karin. 1991. The role of Jun, Fos and the AP-1 complex in cell-proliferation and transformation. Biochim Biophys. Acta. 1072, 129-157.

2. Bogani, P., C. Galli, M. Villa, and F. Visioli. 2007. Postprandial anti-inflammatory and antioxidant effects of extra virgin olive oil. Atherosclerosis 190, 181-186.

3. Bullo, M., M. R. Peeraully, P. Trayhum, J. Folch, and J. Salas-Salvado. 2007. Circulating nerve growth factor levels in relation to obesity and the metabolic syndrome in women. Eur. J. Endocrinol. 157, 303-310.

4. Chae, C. H., S. L. Jung, S. H. An, B. Y. Park, S. W. Wang, I. H. Cho, J. Y. Cho, and H. T. Kim. 2009. Treadmill exercise improves cognitive function and facilitates nerve growth factor signaling by activating mitogen-activated protein kinase/extracellular signal-regulated kinase $1 / 2$ in the streptozotocin-induced diabetic rat hippocampus. Neuroscience 164, 1665-1673.

5. Chen, L., L. Liu, Y. Luo, and S. Huang. 2008. MAPK and mTOR pathways are involved in cadmium-induced neuronal apoptosis. J. Neurochem 105, 251-261.

6. Cotman, C. W. and C. Engesser-Cesar. 2002. Exercise enhances and protects brain function. Exerc. Sport. Sci. Rev. 30, 75-79.

7. Derijard, B., M. Hibi, I. H. Wu, T. Barrett, B. Su, T. Deng, M. Karin, and R. J. Davis. 1994. JNK1: a protein kinase stimulated by UV light and Ha-Ras thst bind and phosphorylates the c-jun activation domain. Cell 76, 1025-1037.

8. Furukawa, S., T. Fujita, M. Shimabukuro, M. Iwaki, Y. Yamada, Y. Nakajima, O. Nakayama, M. Makishima, M. Matsuda, and I. Shimomura. 2004. Increased oxidative stress in obesity and its impact on metabolic syndrome. J. Clin. Invest. 114, 1752-1761.

9. Hebben, N., S. Corkin, H. Eichenbaum, and K. Shedlack. 1985. Diminished ability to interpret and report internal states after bilateral medial temporal resection: case H.M. Behav. Neurosci. 99, 1031-1039.

10. Heled, Y., Y. Shapiro, Y. Shani, D. S. Moran, L. Langzam, L. Braiman, S. R. Sampson, and J. Meyerovitch. 2002. Physical exercise prevents the development of type 2 diabetes mellitus in Psammomys obesus. Am J. Physiol. Endocrinol. Metab. 282, E370-E375.

11. Hempstead, B. L. 2006. Dissecting the diverse actions of proand mature neurotrophins. Curr. Alzheimer. Res. 3, 19-24.

12. Huang, E. J. and L. F. Reichardt. 2003. Trk receptors: roles in neuronal signal transduction. Annu. Rev. Biochem 72, 609-642.

13. Iemitsu, M., S. Maeda, S. Jesmin, T. Otsuki, Y. Kasuya, and T. Miyauchi. 2006. Activation pattern of MAPK signaling in the hearts of trained and untrained rats following a single bout of exercise. J. Appl. Physiol. 101, 151-163.

14. Kakar, M., H. Nystrom, L. R. Aarup, T. J. Nottrup, and D. R. Olsen. 2005. Respiratory motion prediction by using the adaptive neuro fuzzy inference system (ANFIS). Phys. Med Biol. 50, 4721-4728.

15. Kanoski, S. E., R. L. Meisel, A. J. Mullins, and T. L. Davidson. 2007. The effects of energy-rich diets on discrimination reversal learning and on BDNF in the hippocampus and prefrontal cortex of the rat. Behav. Brain Res. 182, 57-66.

16. Kornhauser, J. M., D. E. Nelson, K. E. Mayo, and J. S. Takahashi. 1992. Regulation of jun-B messenger RNA and AP-1 activity by light and a circadian clock. Science 255, 1581-1584.

17. Levinger, I., C. Goodman, V. Matthews, D. L. Hare, G. Jerums, A. Garnham, and S. Selig. 2008. BDNF, metabolic risk factors, and resistance training in middle-aged individuals. Med Sci. Sports Exerc. 40, 535-541.

18. Molteni, R., R. J. Barnard, Z. Yinq, C. K. Roberts, and F. Gómez-Pinilla. 2002. A high-fat, refined sugar diet reduces hippocampal brain-derived neurotrophic factor, neuronal plasticity, and learning. Neuroscience 112, 803-814.

19. Neeper, S. A., F. Gomez-Pinilla, J. Choi, and C. W. Cotman 1995. Exercise and brain neurotrophins. Nature 373, 109.

20. Nisoli, E., C. Tonello, M. Benarese, P. Liberini, and M. O. Carruba. 1996. Expression of nerve growth factor in brown adipose tissue: implications for thermogenesis and obesity. Endocrinology 137, 495-503.

21. Oladehin, A. and R. S. Waters. 2001. Location and distribution of Fos protein expression in rat hippocampus followting acute moderate aerobic exercise. Exp. Brain. Res. 137, 26-35.

22. Radak, Z., T. Kaneko, S. Tahara, H. Nakamoto, J. Pucsok, M. Sasvari, C. Nyakas, and S. Goto. 2001. Regular exercise imporves cognitive function and decreases oxidative damage in rat brain. Neurochem Int. 38, 17-23.

23. Radak, Z., A.W. Taylor, H. Ohno, and S. Goto. 2001b. Adaptation to exercise induced oxidative stress: from muscle to brain. Exerc. Immunol. Rev. 7, 90-107.

24. Radak, Z., A. Toldy, Z. Szabo, S. Siamilis, C. Nyakas, G. Silye, J. Jakus, and S. Goto. 2006. The effects of training and detraining on memory, neurotrophins and oxidative stress markers in rat brain. Neurochem Int. 49, 387-392.

25. Rajala, M. W. and P. E. Scherer. 2003. Minireview: The adipocyte-at the crossroads of energy homeostasis, inflammation, and atherosclerosis. Endocrinology 144, 3765-3773.

26. Ruwhof, C. and A. van der Laarse. 2000. Mechanical stress-induced cardiac hypertrophy: mechanisms and signal transduction pathways. Cardiovasc. Res. 47, 23-37.

27. Schulz, K. H., S. M. Gold, J. Witte, K. Bartsch, U. E. Lang, R. Hellweg, R. Reer, K. M. Braumann, and C. Heesen. 2004. Impact of aerobic training on immune-endocrine parameters, neurotrophic factors, quality of life and coordinative function in multiple sclerosis. J. Neurol. Sci. 225, 11-18.

28. Seger, R. and E. G. Krebs. 1995. The MAPK signaling cascade. FASEB. J. 9, 726-735.

29. Siamilis, S., J. Jakus, C. Nyakas, A. Costa, B. Mihalik, A. 
Falus, and Z. Radak. 2009. The effect of exercise and oxidant-antioxidant intervention on the levels of neurotrophins and free radicals in spinal cord of rats. Spinal Cord 47, 453-457.

30. Sim, K. J., H. Kim, M. S. Shin, H. K. Chang, M. C. Shin, I. G. Ko, K. J. Kim, T. S. Kim, B. K. Kim, Y. T. Rhim, S. Kim, H. Y. Park, J. W. Yi, S. J. Lee, and C. J. Kim 2008. Effect of postnatal treadmill exercise on c-Fos expression in the hippocampus of rat pups born from the alcohol-intoxicated mothers. Brain Dev. 30, 118-125.

31. Steers, W. D. and J. B. Tuttle. 2006 Mechanisms of Disease: the role of nerve growth factor in the pathophysiology of bladder disorders. Nat. Clin. Pract. Urol. 3, 101-110.

32. Suzuki, K., Y. Ito, J. Ochiai, Y. Kusuhara, S. Hashimoto, S. Tokudome, M. Kojima, K. Wakai, H. Toyoshima, K. Tamakoshi, Y. Watanabe, N. Hayakawa, M. Maruta, M. Watanabe, K. Kato, Y. Ohta, and A. Tamakoshi. 2003. Relationship between obesity and serum markers of oxidative stress and inflammation in Japanese. Asian Pac. J. Cancer Prev. 4, 259-266.

33. Sweatt, J. D. 2004. Mitogen-activated protein kinases in synaptic plasticity and memory. Curr. Opin. Neurobiol. 14, 311-317.

34. Thoenen, H. 2000. Neurotrophins and activity-dependent plasticity. Prog. Brain Res. 128, 183-191.

35. Toldy, A., K. Stadler, M. Sasvári, J. Jakus, K. J. Jung, H. Y. Chung, I. Berkes, C. Nyakas, and Z. Radák. 2005. The effect of exercise and nettle supplementation on oxidative stress markers in the rat brain. Brain Res. Bull. 65, 487-493.

36. Wirth, M. J., A. Brun, J. Grabert, S. Patz, and P. Wahle. 2003. Accelerated dendritic development of rat cortical pyramidal cells and interneurons after biolistic transfection with BDNF and NT4/5. Development 130, 5827-5838.

37. Yanagita, S., S. Amemiya, S. Suzuki, and I. Kita. 2007. Effects of spontaneous and forced running on activation of hypothalamic corticotropin-releasing hormone neurons in rats. Life Sci. 80, 356-363.

38. Yu, Y., Q. Wang, and X. F. Huang. 2009. Energy-restricted pair-feeding normalizes low levels of brain-derived neurotrophic factor/tyrosine kinase B mRNA expression in the hippocampus, but not ventromedial hypothalamic nucleus, in diet-induced obese mice. Neuroscience 160, 295-306.

39. Zheng, H., Y. F. Li, K. G. Cornish, I. H. Zucker, and K. P. Patel. 2005. Exercise training improves endogenous nitric oxide mechanisms within the paraventricular nucleus in rats with heart failure. Am J. Physiol. Heart Circ. Physiol. 288, 2332-2341.

초록 : 트레드밀 트레이닝이 비만 쥐의 neurotrophins와 초기발현 단백질에 미치는 영향

우진희 ${ }^{1} \cdot$ 신기옥 $\cdot$ 여남회 ${ }^{1} \cdot$ 박소영 ${ }^{2}$. 강성훈, ${ }^{1,2}$

( ${ }^{1}$ 동아대학교 체육학과, ${ }^{2}$ 동아대학교 약리학 교실)

본 연구는 고지방식이로 인한 비만으로 불균형된 지질구성과 산화적 손상이 신경세포형성과 초기발현단백질 에 미치는 생물학적 영향을 알아보고, 규칙적인 운동의 효과를 알아보기 위하여 실시하였다. 실험동물은 4 주령 $\mathrm{SD}$ rat 수컷 30 마리를 1 주간의 적응기간을 둔 뒤, 15 주간 고지방식이를 통해 비만으로 유도하였으며, high fat diet sedentary (HDS, n=15)와 high fat diet and training ( $\mathrm{HDT}, \mathrm{n}=15$ )으로 분류하여 연구하였다. 운동강도는 $1 \sim 4$ 주는 저강도, 5 8주는 중강도로 주5회 실시하였다. 8주 트레이닝 후 혈청지질, 8-OHdG, MDA, neurotrophic factor, 그리고 IEG를 분석하였다. 그 결과 TC와 TG에서 $\mathrm{HDS}$ 와 $\mathrm{HDT}$ 사이 유의한 차이가 나타났다 $(p<0.05)$. 8-OHdG에서 HDT는 트레드밀 트레이닝 후에 HDS보다 낮게 나타났다( $p<0.05)$. 해마에서 c-jun, BDNF 그리고 간에서 $\mathrm{MDA}$ 의 단백질 발현은 $\mathrm{HDT}$ 가 트레드밀 트레이닝 후 $\mathrm{HDS}$ 보다 높게 나타났다( $p<0.05)$. 결론적으로 8 주간 트레드밀 훈련은 고지방식이 비만 유도 쥐의 혈청지질 성분의 불균형을 개선시키고, 조직과 혈청의 산화적 손상 과 DNA 손상을 완화시켜 주어, 비만으로 인한 합병증 예방에 도움을 줄 수 있을 것으로 사료된다. 또한 NT의 발현을 증가시킴으로써 손상된 뇌기능과 신경세포의 생성 기전 활동에 긍정적 영향을 나타냄으로써 공간적 학습 기능의 향상을 가져온 것으로 판단된다. 